\title{
An Integrated Geochemical and Mineralogical Approach for the Evaluation of Zn Distribution in Long-Term Sludge-Amended Soil
}

\author{
Dominique Proust \\ LIENSs UMR 7266 CNRS, La Rochelle, France \\ Email: dominique.proust@univ-Ir.fr
}

Received 16 October 2015; accepted 20 November 2015; published 23 November 2015

Copyright (C) 2015 by author and Scientific Research Publishing Inc.

This work is licensed under the Creative Commons Attribution International License (CC BY). http://creativecommons.org/licenses/by/4.0/

\section{(c) (i) Open Access}

\section{Abstract}

This research work was designed to compare the $\mathrm{Zn}$ distribution in a long-term sludge-amended soil with that in a control soil. Two complementary approaches were performed: 1) a geochemical approach at the metric scale of the bulk soil horizons and 2) a mineralogical approach at the micrometric scale of the primary minerals weathering microsites. The geochemical approach revealed that $\mathrm{Zn}$ in the control soil was inherited from the weathering parent-rock. Its concentration was always lower than in the amended soil where $\mathrm{Zn}$ was supplied at the surface by the spread sludges and moves downwards. The mineralogical approach showed that the clay minerals, produced by the weathering of the primary minerals (amphiboles and plagioclases), or filling the fissure network were made up of smectites (saponite and montmorillonite) at the bottom and kaolinite at the top of the two soil profiles. Each clay mineral, with its specific sorption capacity, controlled the $\mathrm{Zn}$ distribution within the soil: the smectites produced by the amphiboles had high sorption capacity and favored $\mathrm{Zn}$ retention in the upper horizons of the soil. Conversely, the kaolinites produced by the plagioclases had lower sorption capacity, did not retain $\mathrm{Zn}$ in the surface horizons, and allowed it to migrate to deeper horizons where it was sorbed onto the montmorillonites.

\section{Keywords}

Weathering, Soil, Clay Minerals, Heavy Metal, Zinc

\section{Introduction}

The spreading of sewage sludges onto farmlands can be a beneficial method for soil amendment because the

How to cite this paper: Proust, D. (2015) An Integrated Geochemical and Mineralogical Approach for the Evaluation of Zn Distribution in Long-Term Sludge-Amended Soil. Open Journal of Soil Science, 5, 251-265. 
sludges can be a source of plant nutrients (especially N, P) and organic matter. However, much of these sludges results from the treatment of industrial and urban by-products and may contain toxic organic and inorganic compounds. Among the inorganic components, the heavy metals have been critically examined since some of them can be toxic to the biosphere at very low concentrations: for instance, Cd concentration cannot exceed 2 $\mu \mathrm{g} \cdot \mathrm{g}^{-1}$ for soils to be selected for sludge spreading [1]. The origin of the heavy metals in a soil is either geogenic if they are inherited from the weathering of the parent-rock [2]-[4], or anthropogenic if they come, among other sources, from contamination by repeated application of inorganic fertilizers [5], sludge spreading [6], and/or diffuse atmospheric contamination [7]. One of the most valuable properties of soil as regards sludge-spreading is its ability to absorb and retain the heavy metals ions. The heavy metals adsorption/desorption reactions occur at the soil solid/solution interface and involve especially the clay minerals which are the essential reactive solid components in soils. These clay minerals, with their natural sorptive capacities for heavy metals, are of particular relevance for sludge spreading and have received considerable attention in the last decades [8]-[10].

The adsorption of heavy metals onto clay minerals operates in particular sites with permanent or variable negative charges [11] [12]. The sites with permanent charges are located at the interlayer basal surfaces of the clay minerals and result from the isomorphic substitutions of $\mathrm{Al}^{3+}$ for $\mathrm{Si}^{4+}$ in the silica tetrahedral sheet and/or $\mathrm{Fe}^{2+} / \mathrm{Mg}^{2+}$ for $\mathrm{Al}^{3+}$ in the alumina octahedral sheet. These interlayer negative charges are neutralized by $\mathrm{pH}$-independent adsorption of cations as outer-sphere complexes (cation exchange reactions). The sites with variable charges are located at the crystal edge surfaces and originate in the protonation or deprotonation of surface hydroxyl (SOH) groups. These sites promote $\mathrm{pH}$-dependent adsorption attributed to surface complexation reactions with silanol and aluminol groups to form inner-sphere complexes.

The major part of the clay minerals found in the soils results from the weathering of the parent-rock in two simultaneous processes: i) the dissolution of the primary rock-forming minerals with the release of the cations and the heavy metals; and ii) the crystallization of clay minerals from the soil solutions with the sorption of the previously released heavy metals. Mineralogical studies have shown that the chemical weathering reactions and their associated metals release are active in specific soil microsystems with their own solid and solution chemical properties [13]-[15]. They are typically micrometric composite aggregates of clay minerals (specific to the primary mineral being weathered), oxihydroxides, and organic matter moistened with soil solutions.

Up to now, studies dealing with polluted soils described heavy metals contaminations at the soil scale, i.e. in the fine earth $(<2 \mathrm{~mm})$ of each soil horizon [16] [17] and/or in separated soil fractions, e.g. $<2 \mu \mathrm{m}$ clay fraction or 2 - $50 \mu \mathrm{m}$ silt fraction [18] [19]. These conventional pedological approaches, however, underestimate the influence of the individual soil components, especially the weathering microsystems, upon the adsorption and retention of heavy metals in soils.

Even though the bulk concentrations of heavy metals can be decisive in assessing global soil pollution, they result from the addition of the partial heavy metals concentrations in each of the weathering microsystems. As a consequence, the detailed analysis of a soil contaminated with heavy metals requires both the knowledge of its bulk metals concentration but also the partial metals contents in the microsystems in which they are retained. By taking advantage of a long-term spreading on soil of highly Zn concentrated sewage sludges $\left(498 \mathrm{mg} \cdot \mathrm{kg}^{-1}\right)$, this study is undertaken to estimate i) the impact of the sludge application upon Zn distribution and migration in the soil and ii) the influence of the clay mineral species upon $\mathrm{Zn}$ retention in the weathering microsystems.

\section{Materials and Methods}

\subsection{Soil Characteristics}

The soils investigated in this study were selected and sampled during the geological and pedological field survey of the "Saint-jean-Ligoure" diorite massif in Haute-Vienne (Limousin, France), $25 \mathrm{~km}$ in the South of Limoges (Figure 1). They are inceptisols where wet sewage sludges were deposited during the 90's, each year for ten years, at an application rate of $2500 \mathrm{~kg} \cdot \mathrm{ha}^{-1} \cdot \mathrm{year}^{-1}$ with mean $\mathrm{Zn}$ concentration of $498 \mathrm{mg} \cdot \mathrm{kg}^{-1}$. Two soils were sampled on the same dioritic parent-rock: the Amended Soil (AS) that received the sewage sludges for ten years and the Control Soil (CS) that is free of sludge spreading.

The two soils are moderately drained, deep with the weathered rock found at $100-150 \mathrm{~cm}$ depth and show the typical A, Bw and C horizons sequence of inceptisols (Figure 2(a), Figure 2(b)). The R horizon, i.e. the coherent unweathered parent rock (Figure 2(c)), is a diorite which appears to the naked eye as a "salt and pepper" coarse-grained rock made up of major amphiboles, plagioclases, and minor quartz. The two soils have 


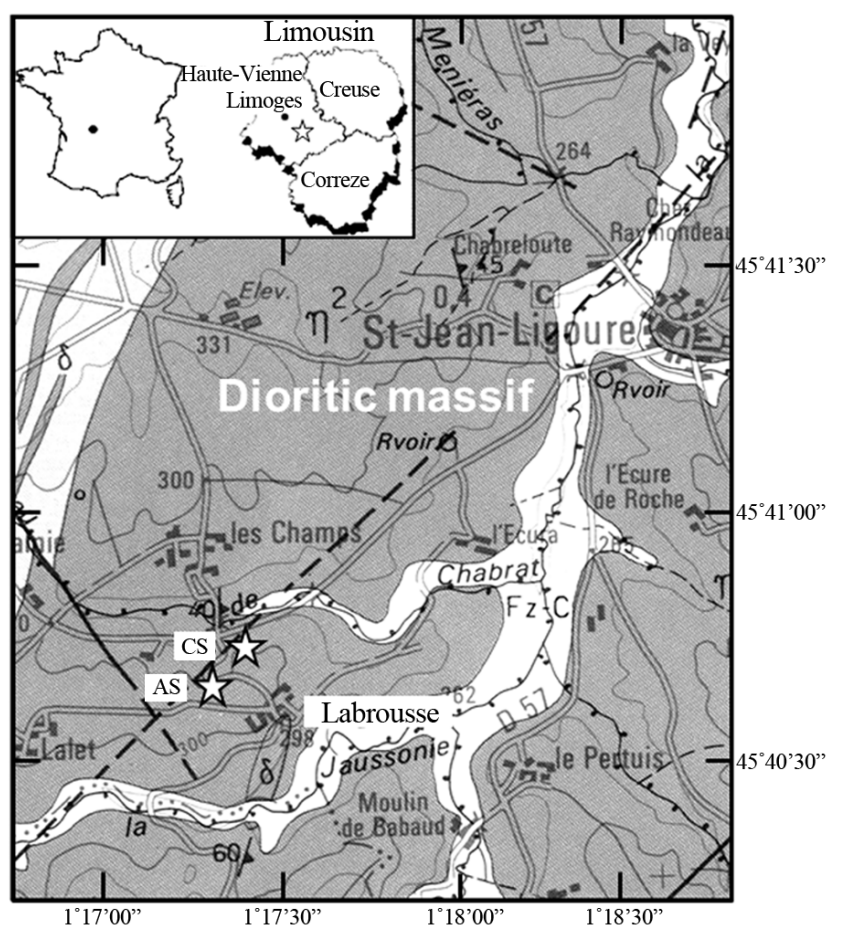

Figure 1. Geological map of the sudied area in the Limousin region, France, and location of the sampled soil profiles; CS:control soil, AS: Amended Soil.

(a)

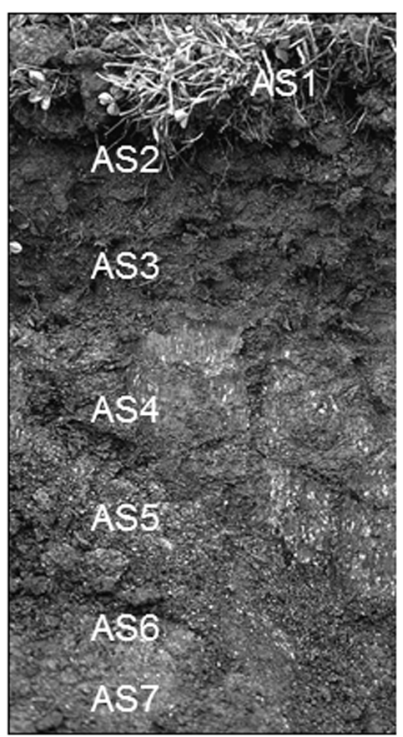

(d)

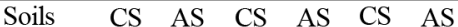
Horizons A A $\mathrm{Bw} \quad \mathrm{Bw} \quad \mathrm{C} \quad \mathrm{C}$ \begin{tabular}{llllllll}
\hline pH water 6.10 & 6.50 & 6.40 & 6.80 & 6.50 & 6.80
\end{tabular} $\begin{array}{lllll}\text { Org. C\% } & 1.92 & 1.82 & 0.63 & 0.85\end{array}$

C.E.C.* 31.9026 .9030 .8027 .9027 .5026 .80 Clay \% 27.9029 .7028 .7031 .8025 .2024 .20

Figure 2. Sketch of the soil profiles; (a) Amended Soil (AS); (b) Control Soil (CS); (c) Parent-rock (R horizon); (d) Bulk physico-chemical properties of soils. (b)

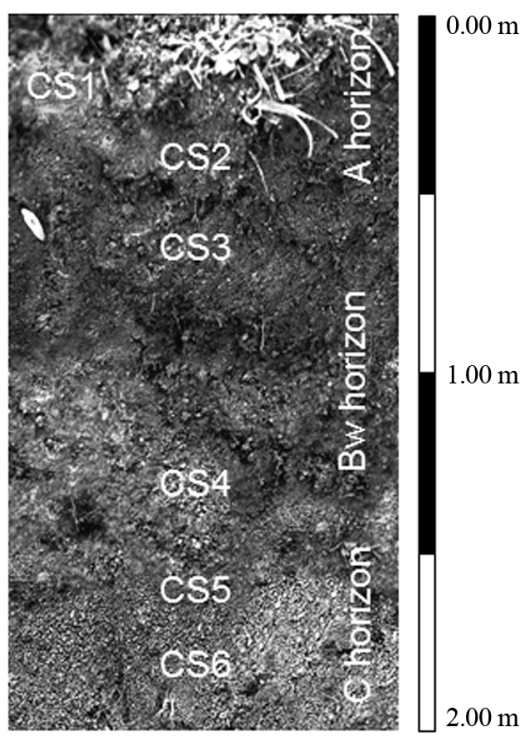

(c)

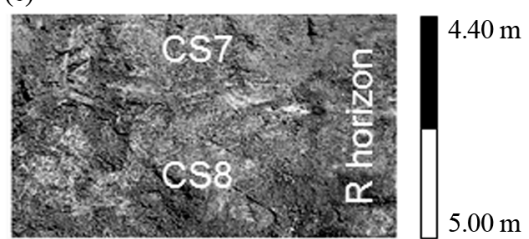


very similar physicochemical properties (Figure 2(d)) with slightly acidic to almost neutral $\mathrm{pH}$ in all horizons (6.1 - 6.8). The $\mathrm{pH}$ values increase with depth, suggesting some leaching of base cations or probably the effect of organic matter with $1.82 \%$ to $1.95 \%$ organic carbon content in the A horizons, decreasing to $0.85 \%-0.63 \%$ in the Bw horizon and disappearing in the $\mathrm{C}$ horizon. The cation exchange capacities of the two soils are similar with medium values ranging between 26.8 and $31.9 \mathrm{cmol} \cdot \mathrm{kg}^{-1}$, whereas the clay contents, typical of the clay loam texture observed in the inceptisols, increase slightly in the Bw horizon (cambic horizon).

\subsection{Sampling Methods}

Each soil was carefully sampled using plastic cylindrical corers to prevent the soil metal contamination. The cylinder, $10 \mathrm{~cm}$ long with a diameter of $10 \mathrm{~cm}$, had cutting edges. It was smoothly and continuously pushed into the soil to collect undisturbed blocks which retained the original soil structure. Each core was divided into two subsamples. The first was disaggregated by gentle shaking in water, sieved to $2 \mathrm{~mm}$, air dried and reserved for the mineral grains separation, the bulk chemical and the X-ray diffraction (XRD) analyses.

The second subsample was preserved undisturbed for thin sections preparation, electron probe microanalyses (EPMA) and scanning electron microscope (SEM) study.

\subsection{Mineralogical Separation}

The organic matter in the first $<2 \mathrm{~mm}$ subsample was removed using 33\% hydrogen peroxide. 200 grams of this sample were shaken in water to destroy the aggregates, sieved into the sandy fractions 50 - $100 \mu \mathrm{m}, 100-150$ $\mu \mathrm{m}, 150-250 \mu \mathrm{m}, 250-500 \mu \mathrm{m}$, and dried at $50^{\circ} \mathrm{C}$ for $24 \mathrm{~h}$. The observation of each sieved fraction under optical microscopy (OM) revealed that most euhedral monomineralic grains were found in the $250-500 \mu \mathrm{m}$ fraction. The smaller sized fractions were made up of broken primary minerals. About 500 monomineralic grains, 250 to $500 \mu \mathrm{m}$ in size, of amphiboles and plagioclases (the two most important minerals in the parent-rock and soils) were then needle-sorted under the stereomicroscope for the study of their specific weathering products. Separation efficiency was checked by XRD.

\subsection{Bulk Chemical Analyses}

The bulk chemical analyses were obtained from the first subsample, freed of its organic matter. An aliquot quantity of matter ( $5 \mathrm{~g}$ ) was collected by quartering with a riffle splitter and crushed down to less than $50 \mu \mathrm{m}$ size into agate mortar. $300 \mathrm{mg}$ were taken from the total powder, fused with $\mathrm{LiBO}_{2}$ at $1050^{\circ} \mathrm{C}$ and dissolved in $1 \mathrm{~N} \mathrm{HNO}_{3}$ for the bulk chemical analyses. The major and trace elements were analysed using ICP-AES and ICP-MS at the Service d'Analyse des Roches et des Minéraux, (SARM), CRPG-CNRS (Vendoeuvre-lès-Nancy, France). The major and trace elements concentrations were expressed in wt.\% and $\mathrm{mg} \cdot \mathrm{kg}^{-1}$, respectively.

\subsection{X-Ray Diffraction Analyses}

The bulk clay fractions, together with the clay minerals extracted from the weathered monomineralic grains by sonification, were analysed by XRD on Ca-saturated oriented preparations, air dried and glycolated. The diffractometer was a PHILIPS PW $1730(40 \mathrm{kV}, 40 \mathrm{~mA})$ with a Fe-filtered $\mathrm{CoK} \alpha$ radiation and a stepping motor driven with a DACO-MP recorder and the Diffrac-AT software (Socabim, Munich, Germany). The bulk clay fraction $<2 \mu \mathrm{m}$ was extracted from $10 \mathrm{~g}$ of the $<2 \mathrm{~mm}$ first subsample. The 10 grams sampled were first dispersed in $350 \mathrm{ml}$ deionized water, sonicated for $2 \mathrm{~min}$ at $300 \mathrm{~W} / 20 \mathrm{kHz}$, then mechanically shaken for $3 \mathrm{~h}$. The stable suspension was then centrifugated at $20^{\circ} \mathrm{C}$ and $1000 \mathrm{rpm}$ for $2 \mathrm{mn} 30 \mathrm{~s}$ with a Jouan JR4.22 centrifuge in order to separate the $<2 \mu \mathrm{m}$ fraction. The effectiveness of this clay separation was then checked using a laser diffraction granulometer IP Malvern Mastersizer.

\subsection{Microanalyses of the Soil Samples}

The second subsample was devoted to the EPMA and the SEM studies. Thin sections were first prepared according to the procedure of Camuti and McGuire [20]. Samples were hardened under vacuum (100 mbars) with an epoxy resin (ARALDITE 2020) mixed with 20\% acetone thinner. After polymerization, samples were cut and thin sections obtained through polishing with silicon carbide (17 $\mu \mathrm{m}$ and $9 \mu \mathrm{m}$ particle sizes) and diamond 
calibrated powders ( $6 \mu \mathrm{m}, 3 \mu \mathrm{m}, 1 \mu \mathrm{m}$, and $0.25 \mu \mathrm{m}$ particle sizes).

Representative pedofeatures (clay coatings, clay cutans, etc.) and weathering microsites were first located on the thin sections, marked with black circle under an optical microscope and then "in situ" analysed for major and trace elements. EPMA were obtained using a CAMECA SX 50 electron microprobe (Service CAMPARIS, Université Paris VI) equipped with wavelength-dispersive spectrometers (WDS). The microprobe was calibrated using synthetic and natural oxides. Corrections were made with a ZAF program. A specific trace program with the electron microprobe was developed [21] to analyse heavy metals in small volumes with detection limits closed to 6 - $8 \mathrm{mg} \cdot \mathrm{kg}^{-1}$. Major elements analyses were performed at $15 \mathrm{kV}$ and $4 \mathrm{nA}$ prior to trace element analysis performed at higher voltage $(30 \mathrm{kV})$ and higher beam current $(100 \mathrm{nA}$ and $500 \mathrm{nA}$ for small and large minerals, respectively) in order to improve detection limits. The spot sizes varied from 1 to 5 - $10 \mu \mathrm{m}$ to limit beam damage. The counting time was $10 \mathrm{~s}$ per major element and 1000s per trace element. Major and trace elements are expressed respectively in $\mathrm{wt} \%$ and $\mathrm{mg} \cdot \mathrm{kg}^{-1}$.

For each dominant primary rock forming mineral, i.e. amphibole and plagioclase, ten grains were selected from the 250 - $500 \mu \mathrm{m}$ needle-sorted fraction and affixed to glass plates with double-sided adhesive tape. The two glass plates were then gold-coated for the micromorphological SEM study of the weathering products.

\subsection{Geochemical Mass Balances}

The geochemical mass balances were obtained from the calculation of enrichment factors $(E F)$ using the method of Hernandez et al. [7] and Sterckeman et al. [4] with the equation:

$$
E F=(X / R)_{\text {altered }} /(X / R)_{\text {reference }}
$$

where the content of element $X$ is normalized to the content of the reference element $R$. A value of 1 for $E F$ indicates no element enrichment or depletion. $E F$ values $>1$ indicate element enrichment and when $<1$ indicate element depletion. The aluminium, with its narrow range of variation in the two soils ( $17.53 \%$ to $20.08 \%$ in Table 1) was chosen as the reference element. The CS8 sample with the lowest loss on ignition suffered very low weathering and was selected as the reference rock for major elements and $\mathrm{Zn}$ bulk analyses.

Table 1. Chemical analyses of major elements (wt\%) and $\mathrm{Zn}\left(\mathrm{mg} \cdot \mathrm{kg}^{-1}\right)$ in control soil (CS) and amended soil (AS) samples.

\begin{tabular}{cccccccccccccccc}
\hline Sample & CS8 & CS7 & CS6 & CS5 & CS4 & CS3 & CS2 & CS1 & AS7 & AS6 & AS5 & AS4 & AS3 & AS2 & AS1 \\
\hline Depth (cm) & 485 & 450 & 180 & 160 & 130 & 65 & 40 & 20 & 190 & 170 & 140 & 110 & 70 & 40 & 20 \\
$\mathrm{SiO}_{2}$ & 48.79 & 49.00 & 47.99 & 47.53 & 47.15 & 49.12 & 47.48 & 46.07 & 51.2 & 50.21 & 51.27 & 52.34 & 50.83 & 51.23 & 50.95 \\
$\mathrm{TiO}_{2}$ & 1.08 & 1.32 & 1.14 & 1.32 & 1.33 & 1.30 & 1.22 & 1.37 & 1.28 & 1.24 & 1.27 & 1.31 & 1.42 & 1.48 & 1.51 \\
$\mathrm{Al}_{2} \mathrm{O}_{3}$ & 18.78 & 18.25 & 19.10 & 19.37 & 19.22 & 19.84 & 20.08 & 18.98 & 18.76 & 18.47 & 18.41 & 17.93 & 18.67 & 17.53 & 18.74 \\
$\mathrm{Fe}_{2} \mathrm{O}_{3}{ }^{\mathrm{a}}$ & 9.58 & 10.04 & 10.03 & 10.08 & 10.29 & 9.41 & 10.13 & 9.75 & 8.87 & 9.53 & 8.99 & 9.47 & 9.26 & 9.65 & 9.13 \\
$\mathrm{MnO}^{2}$ & 0.17 & 0.21 & 0.18 & 0.19 & 0.21 & 0.20 & 0.17 & 0.16 & 0.14 & 0.15 & 0.15 & 0.12 & 0.11 & 0.12 & 0.11 \\
$\mathrm{MgO}$ & 4.47 & 4.55 & 4.20 & 4.06 & 3.89 & 3.88 & 4.09 & 3.52 & 3.25 & 3.44 & 3.19 & 3.29 & 3.36 & 3.36 & 3.08 \\
$\mathrm{CaO}^{2}$ & 7.52 & 6.97 & 6.97 & 7.05 & 6.69 & 6.19 & 4.15 & 6.26 & 5.7 & 5.83 & 5.24 & 2.11 & 3.55 & 2.41 & 4.26 \\
$\mathrm{Na}_{2} \mathrm{O}$ & 3.54 & 3.29 & 3.36 & 3.13 & 2.94 & 3.25 & 3.88 & 2.82 & 3.19 & 3.08 & 3.19 & 3.5 & 2.96 & 3.18 & 3.25 \\
$\mathrm{~K}_{2} \mathrm{O}$ & 1.44 & 1.40 & 1.50 & 1.19 & 1.37 & 1.27 & 1.51 & 1.47 & 1.54 & 1.35 & 1.69 & 1.68 & 1.66 & 1.64 & 1.63 \\
$\mathrm{P}_{2} \mathrm{O}_{5}$ & 0.59 & 0.70 & 0.60 & 0.66 & 0.70 & 0.67 & 0.47 & 0.57 & 0.00 & 0.00 & 0.00 & 0.00 & 0.00 & 0.00 & 0.00 \\
$\mathrm{LOI}$ & 3.77 & 3.94 & 4.68 & 5.21 & 5.04 & 4.62 & 6.50 & 8.53 & 5.91 & 6.48 & 6.19 & 7.77 & 7.74 & 8.49 & 6.72 \\
$\mathrm{Total}^{\mathrm{b}}$ & 99.73 & 99.67 & 99.75 & 99.80 & 98.85 & 99.73 & 99.62 & 99.50 & 99.84 & 99.78 & 99.59 & 99.52 & 99.56 & 99.09 & 99.38 \\
$\mathrm{Zn}$ & 111.18 & 124.46 & 113.06 & 119.32 & 126.08 & 120.42 & 108.24 & 115.56 & 115.36 & 103.04 & 80.64 & 72.15 & 79.64 & 68.27 & 69.29 \\
\hline
\end{tabular}

${ }^{\mathrm{a}}$ Total iron expressed as $\mathrm{Fe}_{2} \mathrm{O}_{3}$. ${ }^{\text {b }} \mathrm{LOI}$ : Loss on ignition. 


\section{Results}

\subsection{Parent-Rock Mineralogy}

The two soils are derived from the same dioritic parent rock which outcrops at the bottom of the quarry exposing the control soil profile (R horizon in Figure 2(c)). The diorite appears to the naked eye as a "salt and pepper" coarse-grained rock made up of major dark-green amphiboles, white plagioclases and minor vitreous quartz. The modal rock composition was obtained from the sample CS8, i.e. the unweathered coherent rock with high apparent density $\left(2.92 \mathrm{~g} \cdot \mathrm{cm}^{-3}\right.$ ) and the lowest loss on ignition (3.77\% in Table 1). The counting of 3000 points on thin section gives the mineralogical composition of 38\% amphibole, $32 \%$ plagioclase, $12 \%$ orthoclase and minor quartz (8\%), albite (7\%), and titanomagnétite (3\%). The EPMA of the major elements in the rock forming minerals show that the amphiboles are calcic hornblendes and plagioclases are andesine with $48 \%$ anorthite content. The EPMA of Zn (Table 2) reveal that the amphiboles are the major Zn-bearing minerals with high Zn concentrations of $180 \mathrm{mg} \cdot \mathrm{kg}^{-1}$ versus lower $\mathrm{Zn}$ contents in the plagioclases $\left(17 \mathrm{mg} \cdot \mathrm{kg}^{-1}\right)$, orthoclase $\left(20 \mathrm{mg} \cdot \mathrm{kg}^{-1}\right)$ and albite $\left(14 \mathrm{mg} \cdot \mathrm{kg}^{-1}\right)$.

\subsection{Geochemical Mass Balances}

The enrichment factors calculated using the Equation (1) and Table 1 are plotted versus depth in Figure 3. The chemical evolution trends from rock to saprolite and soil appear similar for the major elements in the control and amended soils. The first chemical change observed during weathering is the general increase in $E F$ calculated for the loss on ignition (EF-L.O.I.) from bottom to top of the two soil profiles (Figure 3(a)). EF-L.O.I. increases
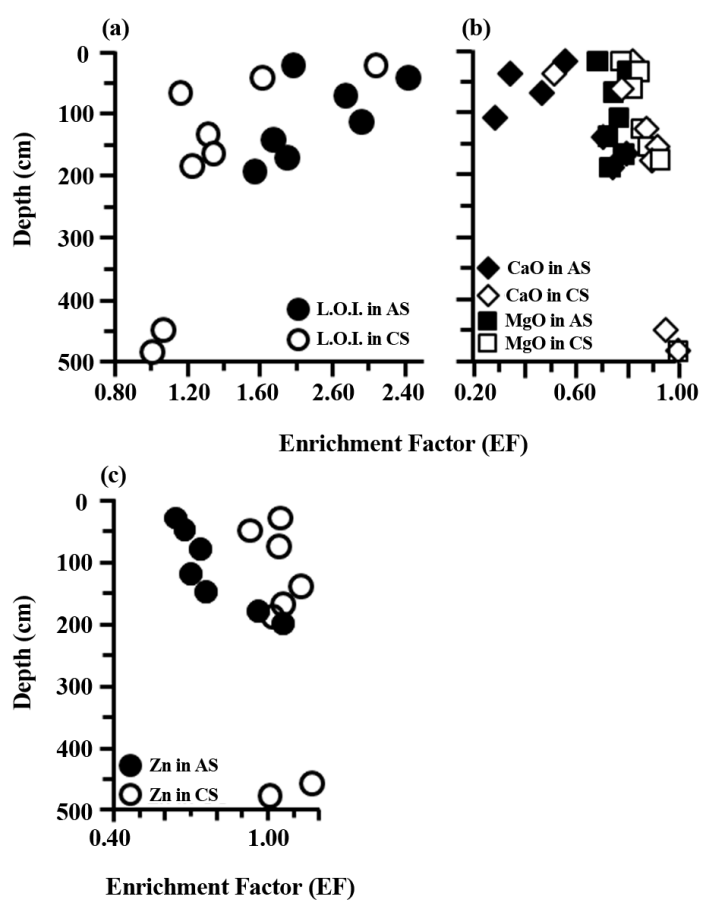

Figure 3. Variations in the enrichment factor (EF) calculated for (a) Loss on Ignition (L.O.I.); (b) $\mathrm{CaO}$ and $\mathrm{MgO}$; (c) $\mathrm{Zn}$ in the amended (AS) and control (CS) soils.

Table 2. Mean EPMA of Zn (nanalyses, $\mathrm{mg} \cdot \mathrm{kg}^{-1}$ ) in the rock-forming minerals.

\begin{tabular}{ccccccccc}
\hline & \multicolumn{2}{c}{ Amphibole } & \multicolumn{2}{c}{ Plagioclase } & \multicolumn{2}{c}{ Orthoclase } & \multicolumn{2}{c}{ Albite } \\
\hline & $n=14^{\mathrm{a}}$ & $\mathrm{SE}^{\mathrm{b}}$ & $n=10$ & $\mathrm{SE}$ & $n=10$ & $\mathrm{SE}$ & $n=10$ & $\mathrm{SE}$ \\
$\mathrm{Zn}$ & 180 & 4 & 17 & 2 & 20 & 2 & 14 & 6 \\
\hline
\end{tabular}

${ }^{\mathrm{a}}$ Each analysis is already the mean of ten measurements. ${ }^{\mathrm{b}}$ Standard error. 
more than twice from the sample reference CS8 $(E F-$ L.O.I. $=1)$ to the top of the soils (EF-L.O.I. reaches 2.41 in the sample AS2 at the top of the amended soil). This trend reflects the general increase in the bulk water content (loss on ignition at $1050^{\circ} \mathrm{C}$, i.e. the hydrate content in the absence of the $\mathrm{CO}_{2}$ found in carbonates and after organic matter destruction), and is related to the increase in the hydrated clay minerals crystallizations as weathering proceeds. In the same way as aluminium that was chosen for reference element, the measured $\mathrm{SiO}_{2}$ and $\mathrm{Fe}_{2} \mathrm{O}_{3}$ concentrations (Table 1 ) remain stable throughout the two soil profiles and give $E F$ values close to 1 (0.91 - 1.12 for $E F-\mathrm{SiO}_{2}$ and 0.93 - 1.08 for $E F-\mathrm{Fe}_{2} \mathrm{O}_{3}$ ). Conversely, the alkaline earth elements $\mathrm{Mg}$ and Ca decrease regularly from the bottom to the top of the two soils: The EF-MgO and EF-CaO reach respectively 0.69 and 0.34 in the sample AS2 at the top of the amended soil (Figure 3(b)). This regular and general decrease in the two soils is indicative of the weathering processes which affect the amphiboles ( $E F-\mathrm{MgO}$ and $E F-\mathrm{CaO})$ and the plagioclases $(E F-C a O)$ in the saprolite and soil.

The chemical analyses of $\mathrm{Zn}$ in the bulk soil horizons (Table 1) reveal that, although the sewage sludges spread on the amended soil were heavily loaded with $\mathrm{Zn}\left(498 \mathrm{mg} \cdot \mathrm{kg}^{-1}\right.$ as mean concentration), its concentration in the two soils never exceeds the threshold value for anthropogenic contamination (300 $\mathrm{mg} \cdot \mathrm{kg}^{-1}$, [22]). The $\mathrm{Zn}$ enrichment factors, when calculated from Table 1 and plotted versus depth in Figure 3(c), reveals two different trends depending on whether the control soil or the amended soil is considered: The distribution of EF-Zn in the control soil does not show any significant variation throughout the soil profile, whereas $E F$ s in the amended soil indicate pronounced depletion of $\mathrm{Zn}$ in the surface horizons that may suggest migration of this metal to depth (down to $190 \mathrm{~cm}$, sample AS7). This Zn migration to depth has been already observed by Scokart et al. [23].

\subsection{Behaviour of $\mathrm{Zn}$ in the Soil Clay Fractions}

The clay minerals identified in the $<2 \mu \mathrm{m}$ granulometric fractions are similar in the control and amended soils. The XRD on Ca-oriented preparations reveals the typical 001 reflections of smectite, at $15.10 \AA$ in air-dried state and shifting to $17.05 \AA$ after ethylene-glycol solvation. The smectite is associated with a kaolinite which is typified, in air-dried and ethylene-glycol solvated states, by 001 and 002 reflections at $7.15 \AA$ and $3.55 \AA$ respectively. These reflections disappear after $450^{\circ} \mathrm{C}$ heating. No reflection of iron oxide or hydroxide was detected on the XRD patterns of the random powders.

The Zn contents in the soil clay fractions were measured using the electron microprobe and are given with their mean standard errors in Table 3. The EPMA are plotted versus depth in Figure 4(a) to follow the Zn distribution in the two soil profiles. It appears in Table 3 that the $\mathrm{Zn}$ concentrations in the bulk clay fractions of the amended soil range from 144 to $203 \mathrm{mg} \cdot \mathrm{kg}^{-1}$ and are always higher than in the control soil where they range from 10 to $24 \mathrm{mg} \cdot \mathrm{kg}^{-1}$. The shape of the $\mathrm{Zn}$ distribution profile in the amended soil (Figure 4(a)) is typically that of a downward migrating element, with $\mathrm{Zn}$ concentrations about ten times that measured in the control soil and a regular decrease from the top to the bottom of the amended soil. The highest $\mathrm{Zn}$ concentrations are measured in the surface horizons, from 195 to $203 \mathrm{mg} \cdot \mathrm{kg}^{-1}$ at $20 \mathrm{~cm}$ (sample AS1) and $40 \mathrm{~cm}$ (sample AS2) depths, decreasing to $150 \mathrm{mg} \cdot \mathrm{kg}^{-1}$ at the bottom of the soil (190 cm depth, sample (AS7)). For comparison, the Zn distribution profile of the control soil does not show significant variations when standard errors are considered

Table 3. Mean EPMA of Zn ( $n$ analyses, $\mathrm{mg} \cdot \mathrm{kg}^{-1}$ ) in the clay fractions of amended (AS) and control (CS) soils.

\begin{tabular}{|c|c|c|c|c|c|c|c|c|c|c|c|c|c|c|c|c|}
\hline & \multicolumn{2}{|c|}{ AS7 } & \multicolumn{2}{|c|}{ AS6 } & \multicolumn{2}{|c|}{ AS5 } & \multicolumn{2}{|c|}{ AS4 } & \multicolumn{2}{|c|}{ AS3 } & \multicolumn{2}{|c|}{ AS2 } & \multicolumn{2}{|c|}{ AS1 } & & \\
\hline \multirow[t]{2}{*}{ Depth (cm) } & \multicolumn{2}{|c|}{190} & \multicolumn{2}{|c|}{170} & \multicolumn{2}{|c|}{140} & \multicolumn{2}{|c|}{110} & \multicolumn{2}{|c|}{70} & \multicolumn{2}{|c|}{40} & \multicolumn{2}{|c|}{20} & & \\
\hline & $n=4^{\mathrm{a}}$ & $\mathrm{SE}^{\mathrm{b}}$ & $n=4$ & SE & $n=4$ & $\mathrm{SE}$ & $n=4$ & SE & $n=4$ & SE & $n=4$ & $\mathrm{SE}$ & $n=4$ & SE & & \\
\hline $\mathrm{Zn}$ & 150 & 12 & 158 & 12 & 144 & 11 & 153 & 10 & 177 & 9 & 203 & 13 & 195 & 12 & & \\
\hline Sample & \multicolumn{2}{|c|}{ CS8 } & \multicolumn{2}{|c|}{ CS7 } & \multicolumn{2}{|c|}{ CS6 } & \multicolumn{2}{|c|}{ CS5 } & \multicolumn{2}{|c|}{ CS4 } & \multicolumn{2}{|c|}{ CS3 } & \multicolumn{2}{|c|}{ CS2 } & \multicolumn{2}{|c|}{ CS1 } \\
\hline \multirow[t]{2}{*}{ Depth (cm) } & \multicolumn{2}{|c|}{485} & \multicolumn{2}{|c|}{450} & \multicolumn{2}{|c|}{180} & \multicolumn{2}{|c|}{160} & \multicolumn{2}{|c|}{130} & \multicolumn{2}{|c|}{65} & \multicolumn{2}{|c|}{40} & \multicolumn{2}{|l|}{20} \\
\hline & $n=4$ & SE & $n=4$ & SE & $n=4$ & SE & $n=4$ & SE & $n=4$ & SE & $n=4$ & SE & $n=4$ & SE & $n=4$ & $\mathrm{SE}$ \\
\hline $\mathrm{Zn}$ & 15 & 2 & 14 & 1 & 14 & 2 & 17 & 2 & 18 & 3 & 19 & 3 & 24 & 5 & 10 & 3 \\
\hline
\end{tabular}

${ }^{a}$ Each analysis is already the mean of ten measurements. ${ }^{b}$ Standard error. 

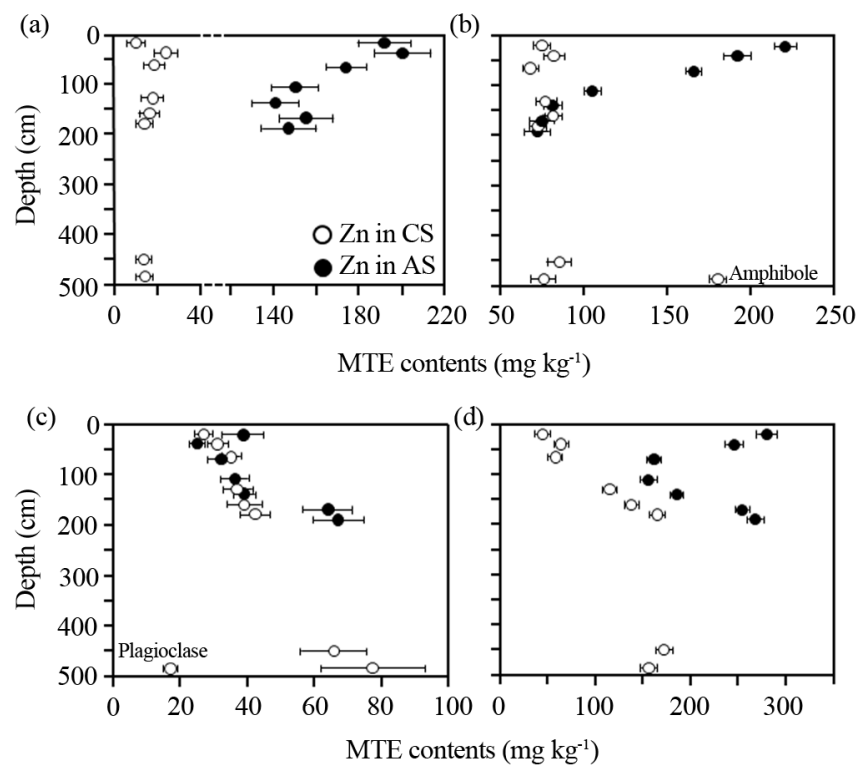

\begin{abstract}
Figure 4. Vertical distribution profile of $\mathrm{Zn}$ in the amended (AS) and control (CS) soils; (a) $\mathrm{Zn}$ concentrations in the $<2 \mu \mathrm{m}$ clay fraction; (b) Zn concentrations in the amphiboles and their clay minerals weathering products; (c) Zn concentrations in the plagioclases and their clay minerals weathering products; (d) Zn concentrations in the fissural clay minerals.
\end{abstract}

(Figure 4(a)). The Zn concentrations are much lower than those measured in the amended soil, and range from 10 to $24 \mathrm{mg} \cdot \mathrm{kg}^{-1}$ at $20 \mathrm{~cm}$ (sample CS1) and $40 \mathrm{~cm}$ (sample CS2) depths, and from 14 to $15 \mathrm{mg} \cdot \mathrm{kg}^{-1}$ at $180 \mathrm{~cm}$ (sample CS6) and $485 \mathrm{~cm}$ (sample CS8) depths.

\title{
3.4. Behaviour of $\mathrm{Zn}$ in the Amphibole Weathering Microsystems
}

The first signs of amphiboles weathering are found in the $\mathrm{C}$ horizons of the two soils. The OM observation of the thin sections reveals that euhedral amphibole prismatic crystals begin to weather along the enlarged cleavage planes (Figure 5(a)) where SEM shows the crystallization of clay minerals with the typical honeycomb texture of the smectite (Figure 5(b)). These characteristic features are commonly observed in the weathered rocks and soils [24] [25]. The weathering intensity increases in the Bw horizons where amphibole crystals appears highly fragmented into $20-100 \mu \mathrm{m}$ organized residues by the opening of the intramineral microcracks, up to $50 \mu \mathrm{m}$ wide (Figure 5(c)). The SEM reveals that the clay minerals filling these microcracks exhibit the same honeycomb morphology of smectite clay minerals, already observed in the C horizons; they are covering the saw-tooth terminations of the dissolving amphibole crystals (Figure 5(d)). The most advanced weathering stages are found in the surface A horizons where the amphiboles crystals are almost entirely replaced by a clayey weathering plasma (Figure 5(e)) made up of smectites with the characteristic honeycomb texture (Figure 5(f)).

The clay minerals, extracted from the amphiboles grains by sonication, were identified by XRD. The XRD patterns are similar in the $\mathrm{C}, \mathrm{Bw}$, and A horizons with the same typical reflections of smectite. The Ca-oriented preparations reveals strong 001 reflections ranging from $14.50 \AA$ to $15.49 \AA$ in air-dried state, shifting to 16.87 $17.14 \AA$ with higher orders at $8.46 \AA$ and $3.40 \AA$ after ethylene-glycol solvation. This expansion to $17 \AA$ with ethylene-glycol is typical of smectite layers.

The EPMA of the amphibole weathering products characterize two chemically distinct smectite populations. The first is detected in the $\mathrm{C}$ horizons of soils and is made up of magnesian smectites belonging to the trioctahedral group of saponites. The second population is found in more advanced weathering stages (Bw and A horizons) as aluminous smectites belonging to the dioctahedral smectite group of montmorillonites.

The $\mathrm{Zn}$ contents in the clay minerals produced by the weathering of amphiboles were measured using the electron microprobe and are given in Table 4 with their mean standard errors. The EPMA are plotted versus depth in Figure 4(b) to follow the behaviour of $\mathrm{Zn}$ in the two soil profiles. The early weathering of amphiboles into saponites (R horizon, samples CS8 and CS7) results into the partial release of $\mathrm{Zn}$, from $180 \mathrm{mg} \cdot \mathrm{kg}^{-1}$ in the 

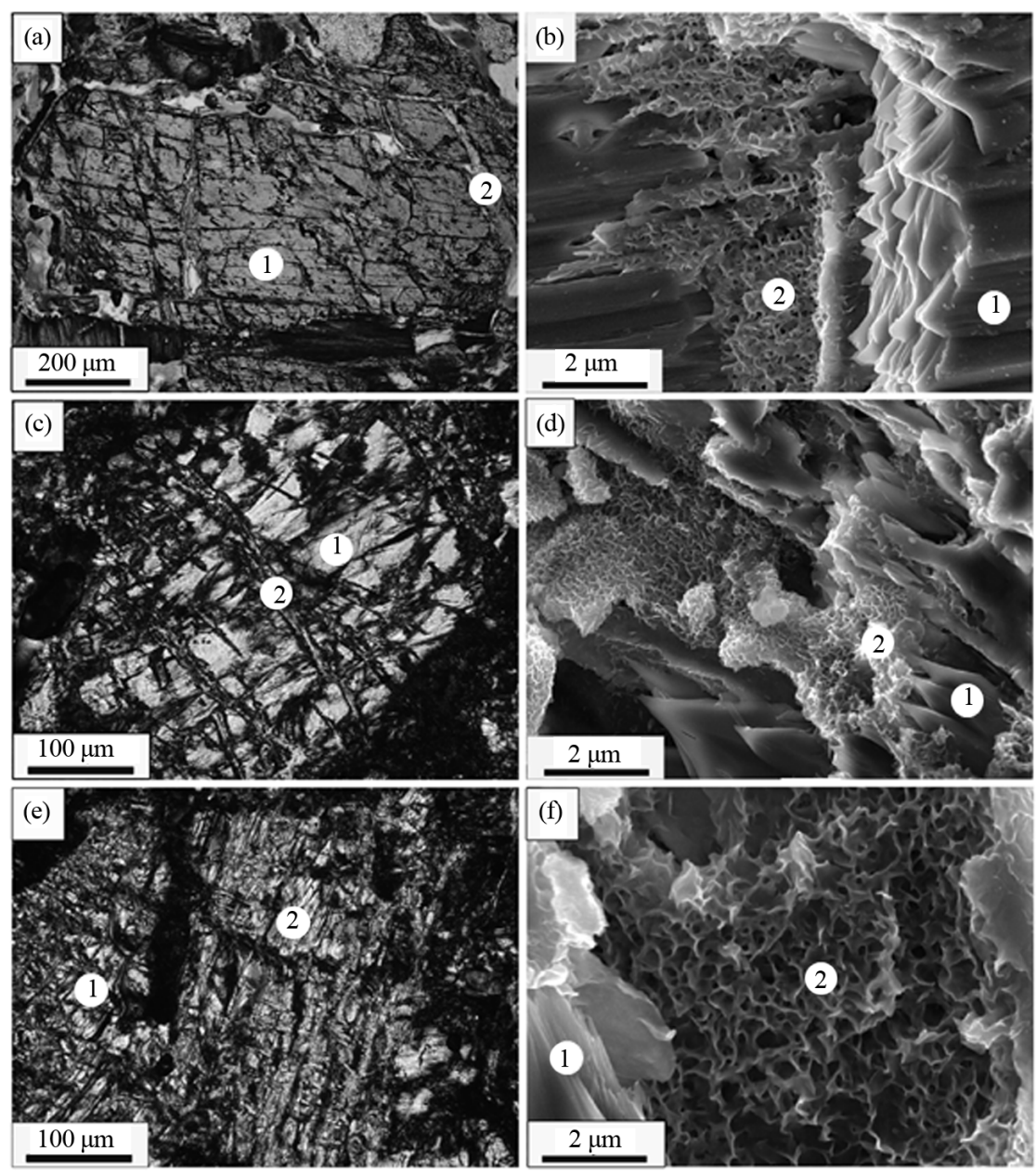

Figure 5. Optical Microscopy (OM) and Scanning Electron Microscopy (SEM) of the amphibole weathering. (a) OM view of an early weathering microsite in the $\mathrm{C}$ horizon of the control soil, with 1: elongated amphibole crystal; 2: intramineralmicrocrack with clay minerals infillings. (b) SEM view of the microsite a) with 1: amphibole crystal; 2 : honeycomb texture of clay minerals in a microcrack. (c) OM view of a weathering microsite in the $\mathrm{Bw}$ horizon of the control soil with 1: amphibole fragments; 2: dense microcrack network with clay minerals infillings. (d) SEM view of the microsite c) with 1: saw-tooth amphibole terminations; 2: honeycomb clay minerals cover. (e) OM view of a weathering microsite in the A horizon of the control soil with 1: increasing amphibole fragmentation with clay minerals crystallizations; 2: complete replacement of amphibole fragments by a clayey plasma. (f) SEM view of the microsite e) with 1 : amphibole fragment; 2: honeycomb-textured clay mineral.

fresh amphibole (Table 2) to $76-85 \mathrm{mg} \cdot \mathrm{kg}^{-1}$ in the saponites. Higher weathering levels in the C, Bw, and A horizons produce different $\mathrm{Zn}$ distributions depending on whether the control or the amended soil is considered.

When taking into account the mean standard errors, the Zn concentrations in saponites and montmorillonites appear almost constant throughout the control soil profile (Figure 4(b)). The behaviour of $\mathrm{Zn}$ in the amended soil appears much more complicated. Initially, the Zn concentrations measured in the saponites derived from amphiboles are very similar in the C horizons of the amended and control soil profiles: 72 to $82 \mathrm{mg} \cdot \mathrm{kg}^{-1}$ in AS7, AS6, AS5 versus 72 to $81 \mathrm{mg} \cdot \mathrm{kg}^{-1}$ in CS6 and CS5 (Table 4, Figure 4(b)). In a second stage, the Zn concentrations measured in the montmorillonites from the $\mathrm{Bw}$ and A horizons of the amended soil differ strongly from that in the control soil. The concentrations increase in the amended soil from 105 to $220 \mathrm{mg} \cdot \mathrm{kg}^{-1}$ in AS4 and AS1 versus 68 to $82 \mathrm{mg} \cdot \mathrm{kg}^{-1}$ in CS4 and CS1 (Table 4, Figure 4(b)). 


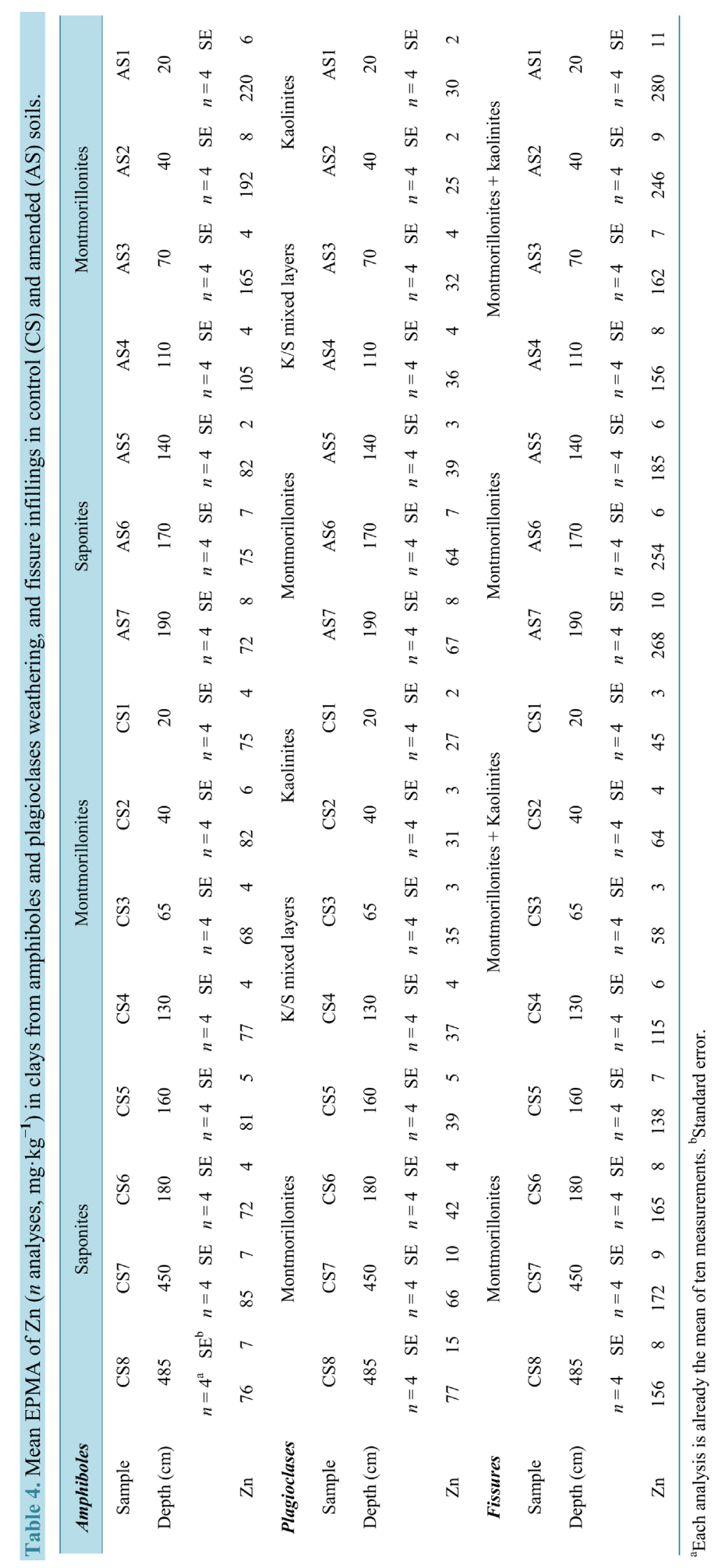




\subsection{Behaviour of Zn in the Plagioclase Weathering Microsystems}

The first weathered plagioclases were observed under OM in the R and C horizons of the two soils. The heart of the plagioclases is dotted with etch pits which are filled by newly-formed clay minerals (Figure 6(a)). The SEM gives more details about these clay minerals which display a typical honeycomb habit, previously observed for the smectites in the amphiboles (Figure 6(b)). The plagioclases observed under OM in the Bw horizons show more advanced weathering stage. The etch pits, more numerous and connected, lead to the fragmentation of the plagioclase crystals into small pieces, $200 \mu \mathrm{m}$ as largest size, with clay minerals patches (Figure 6(c)). The SEM reveals that these clay minerals have a spheroidal habit (Figure 6(d)) very different from the honeycombs observed in the first weathering stage. The most weathered plagioclases are observed in the A horizons. The plagioclase crystals are now almost entirely replaced by a light-grey clayey weathering plasma (Figure 6(e)). The SEM reveals that these clay minerals have an exfoliated "booklet-type" morphology (Figure 6(f)) which is
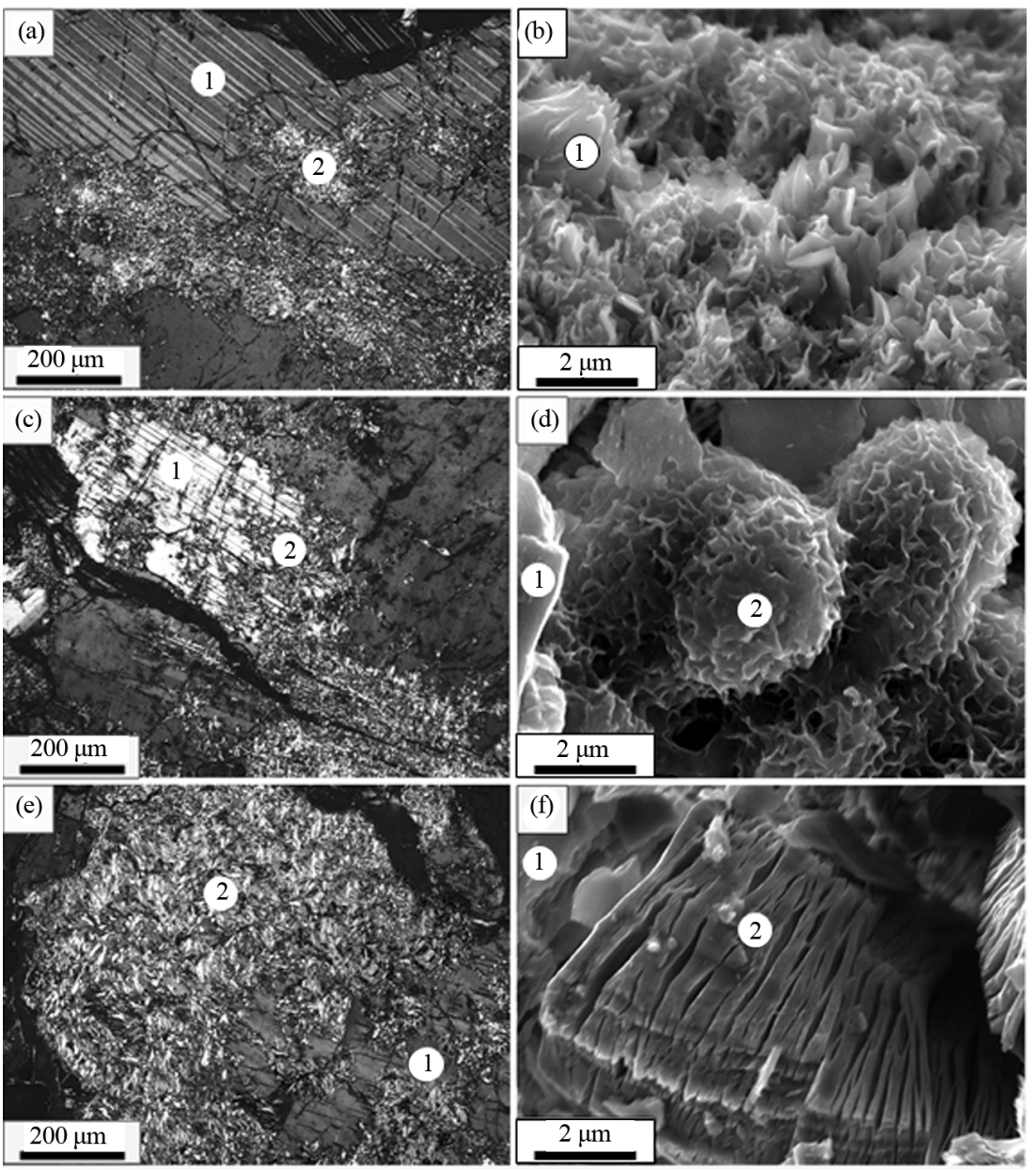

Figure 6. Optical Microscopy (OM) and Scanning Electron Microscopy (SEM) of the plagioclase weathering. (a) $\mathrm{OM}$ view of an early weathering microsite in the $\mathrm{C}$ horizon of the control soil, with 1: tabular plagioclase crystal; 2: clay minerals infilling dissolution pits. (b) SEM view of the microsite a) with 1: honeycomb texture of clay minerals in a dissolution pit. (c) OM view of a weathering microsite in the Bw horizon of the control soil with 1: plagioclase fragmentation; 2: clay minerals infillings in enlarged dissolution pits. (d) SEM view of the microsite c) with 1: plagioclase remnant; 2: spheroidal clay minerals filling a dissolution void. (e) OM view of a weathering microsite in the A horizon of the control soil with 1: increasing plagioclase fragmentation with clay minerals crystallizations; 2: complete replacement of plagioclase fragments by a clayey plasma. (f) SEM view of the microsite e) with 1: plagioclase fragment; 2: "booklet-type"-textured clay mineral. 
commonly observed for the kaolinite crystallizations in the altered rocks [26] [27].

The XRD patterns of the clay minerals extracted from the plagioclase grains differ according to their location in the two soil profiles. The clay minerals in the $\mathrm{C}$ horizon of the two soils are similar and made up of a smectite with a $15.56 \AA$ reflection in Ca-oriented, air-dried state, shifting to $17.06 \AA$ after ethylene-glycol solvation, with a second order reflection at $8.48 \AA$. The XRD patterns of the clay minerals with spheroidal habit (Figure 6(d)) in the Bw horizons are more complex, but similar in the two soils. At the bottom of the Bw horizons (140 - 130 cm depth) XRD characterizes a random kaolinite/smectite (K/S) mixed layer with 65\% smectite component. This clay mineral is typified by its reflections at $15.03 \AA, 7.36 \AA$, and $3.55 \AA$ in Ca-oriented, air-dried state, shifting to $17.14 \AA, 8.28 \AA$, and $3.42 \AA$ after ethylene-glycol solvation. This K/S is replaced at the top of the Bw horizons (70 - $65 \mathrm{~cm}$ depth) by a second random K/S with only 5\% smectite component. This K/S differs from the first one by its very low expansion at $7.36 \AA$ (17.14 $\AA$ for the first K/S) in Ca-oriented, ethylene-glycol solvated state. The XRD of the clay minerals with the exfoliated "booklet-type" observed in the A horizons characterize a kaolinite clay mineral with a typical 7.17 $\AA-4.44 \AA-3.57 \AA$ reflection group in Ca-oriented, air-dried state, unchanged in the Ca-ethylene-glycol-solvated state.

The EPMA of the clay minerals in the weathered plagioclases are in good agreement with the XRD results. The chemical analyses characterize two weathering sequences producing different clay minerals. The first sequence appears in the parent-rock and the $\mathrm{C}$ horizons of soils with the early weathering of plagioclases into aluminous smectites of the montmorillonite group. The second sequence occurs in the $\mathrm{Bw}$ and $\mathrm{A}$ horizons where montmorillonite weathers first into K/S (Bw horizons) and finally into kaolinite (A horizons).

The $\mathrm{Zn}$ concentrations in the clay minerals produced by the weathering of plagioclases are given in Table 4 and plotted versus depth in Figure 4(c). The early plagioclase weathering into montmorillonites leads to a general Zn enrichment from $17 \mathrm{mg} \cdot \mathrm{kg}^{-1}$ in the fresh plagioclase (Table 2) to $77-66 \mathrm{mg} \cdot \mathrm{kg}^{-1}$ (R horizons, samples CS8 and CS7). The Zn distribution in the $\mathrm{C}, \mathrm{Bw}$, and A horizons show similar trends in the control and amended soils. The Zn concentrations in the control soil decrease regularly from $42 \mathrm{mg} \cdot \mathrm{kg}^{-1}$ at $180 \mathrm{~cm}$ depth to 27 $\mathrm{mg} \cdot \mathrm{kg}^{-1}$ at the soil surface (20 cm depth). A similar evolution is observed in the amended soil, but concentrations in the deepest levels are higher: $67 \mathrm{mg} \cdot \mathrm{kg}^{-1}$ at $190 \mathrm{~cm}$ and $64 \mathrm{mg} \cdot \mathrm{kg}^{-1}$ at $170 \mathrm{~cm}$ depths (Figure 4(c)). In both soils, the decrease in $\mathrm{Zn}$ concentrations from bottom to top follow the decrease in smectite contents observed in the clay minerals: $100 \%$ smectite in the C horizons (montmorillonites), followed by $65 \%$ and $5 \%$ smectite in the $\mathrm{K} / \mathrm{S}$ from the Bw horizons and $0 \%$ smectite in the kaolinite from the A horizons.

\subsection{Behaviour of $\mathrm{Zn}$ in the Fissural Microsystems}

The fissural microsystems are made up of grey to light-green clay minerals that aggregate in the fissural network of the weathered rock and soil. This fissural network ranges from $10 \mu \mathrm{m}$ to millimeter in width and the clay minerals are observed as infilling clay material. Since clay minerals could not be separated from the bulk soil samples in sufficient pure amount to use XRD identification, they were characterized in situ from thin sections using EPMA. The clay mineralogy deduced from the EPMA of the major elements evolves from pure montmorillonite at the bottom of the two soils to a mixture of montmorillonite and kaolinite at the top. The vertical distribution profile of Zn (Figure 4(d)) obtained from the EPMA of the clay minerals (Table 4) shows firstly the anthropogenic contamination of the fissural clays by $\mathrm{Zn}$ in the amended soil surface, when compared to the control soil. The $\mathrm{Zn}$ concentrations measured in the amended soil are always higher than in control soil (156 to $280 \mathrm{mg} \cdot \mathrm{kg}^{-1}$ versus 45 to $172 \mathrm{mg} \cdot \mathrm{kg}^{-1}$, Table 4). The vertical distribution of $\mathrm{Zn}$ in the control soil is typical of a downward migrating element, in good correlation with the clay mineralogy (Figure 4(d)). The lowest content (45 mg $\mathrm{kg}^{-1}$, Table 4) is measured in the fissural clays from the surface sample (sample CS1, $20 \mathrm{~cm}$ depth) which are dominated by the kaolinite with very low sorption capacity. $\mathrm{Zn}$ is then allowed to migrate downwards, to be retained in the level where fissural infillings are montmorillonites with high sorption capacities. This occurs from $160 \mathrm{~cm}$ depth in the fissure of the sample CS5 (138 mg. $\left.\mathrm{kg}^{-1}\right)$ down to $485 \mathrm{~cm}$ in the sample CS8 $\left(156 \mathrm{mg} \cdot \mathrm{kg}^{-1}\right)$. The vertical distribution of $\mathrm{Zn}$ in the amended soil is very similar but with higher concentrations and $\mathrm{Zn}$ accumulation in the surface horizons, i.e. 280 - $246 \mathrm{mg} \cdot \mathrm{kg}^{-1}$ in samples AS1 and AS2 at $20-40 \mathrm{~cm}$ depth (Table 4). This surface accumulation, not observed in the control soil, can be directly related to the spreading of the sewage sludges.

\section{Discussion and Conclusions}

In the first place, two meaningful observations must be discussed at the scale of the soil profiles. The first ob- 
servation is that the control and the amended soils have the same diorite parent-rock and developed C, Bw and A horizons with similar physiochemical properties, unmodified by sludge spreading (Figire 2(d)). This is particularly true for the $\mathrm{pH}$ which can affect the variable-charge sites in the clay minerals through protonation or deprotonation of the hydroxyl (SOH) groups. The higher the $\mathrm{pH}$, the higher the adsorption of the heavy metals at the clay-water interfaces [28]-[31] and the lower their mobility [32]. The $\mathrm{pH}$ values measured in the amended soil are even closer to neutrality (6.5 - 6.8) than in the control soil (6.1 - 6.5), and thus it will favor adsorption of the heavy metals at the clay surfaces. The second observation is that the geochemical mass balances display the same major elements distribution in the two soil profiles (Figure 3(a), Figure 3(b)). This distribution is typical of similar weathering and pedogenetic processes with increasing LOI content (crystallization of newly-formed clay minerals), alkaline earth leaching (weathering of primary rock-forming minerals) and stability of $\mathrm{SiO}_{2}$ and $\mathrm{Fe}_{2} \mathrm{O}_{3}$. This latter observation indicates that $\mathrm{SiO}_{2}$ and $\mathrm{Fe}_{2} \mathrm{O}_{3}$, initially released by the weathering of the rockforming minerals, are precipitated in the newly-formed clay minerals and do not leave the soil profiles.

These observations show that the two soils are formed from the same parent-rock and have suffered similar weathering and pedogenetic processes which lead to the same horizons development and the same weathering clay mineralogy (smectites, K/S, kaolinite). These converging data validate the choice of these two soils to follow the behaviour of the $\mathrm{Zn}$ when it is applied to the amended soil by long-term sludge spreading.

The bulk Zn concentrations in the soil samples (Table 1) remain always below the value of $300 \mathrm{mg} \cdot \mathrm{kg}^{-1}$, upper threshold value for non-polluted soil in the French regulation. Thus, repeated sludge spreadings on the area do not induce Zn pollution. The distribution of the EF-Zn versus depth in the amended soil (Figure 3(c)) shows a pronounced $\mathrm{Zn}$ depletion from the surface horizons which weakens downward and indicates Zn migration down to $190 \mathrm{~cm}$ depth. These data reflect the behaviour of zinc at the scale of the soil sample, but a further study of the soil components indicates that local $\mathrm{Zn}$ concentrations may occur in specific soil compartments such as the $<2 \mu \mathrm{m}$ clay fraction, the weathering microsites at the scale of the rock-forming minerals, or the fissural network.

The $\mathrm{Zn}$ concentrations in the $<2 \mu \mathrm{m}$ clay fractions of the amended soil (Table 3) reveal clearly the anthropogenic contamination of the clay minerals in the surface horizons (20 to $40 \mathrm{~cm}$ depth) when compared to the control soil. This surface contamination is associated with the downward $\mathrm{Zn}$ migration down to $190 \mathrm{~cm}$ depth (Figure 4(a)). These clay fractions, however, are the collection of the clay minerals which have formed during the weathering of the rock-forming minerals or have migrated in the fissural network. Thus, the study of $\mathrm{Zn}$ behaviour in the two soils will be greatly improved by considering the clay minerals in their crystallization sites, i.e. at the micrometric scale of the thin section.

The $\mathrm{Zn}$ distribution profiles collected from the amphiboles weathering microsites (Figure 4(b)) reveal a general anthropogenic contamination of the amended surface horizons with $\mathrm{Zn}$. This contamination can be related to the crystallization of large amount of montmorillonite as weathering product of amphibole. This montmorillonite, with high sorption capacity of 90 to $127 \mathrm{cmol} \cdot \mathrm{kg}^{-1}$ [33] [34] may fix a part of Zn provided by the sludges in the surface horizons. This surface accumulation is followed by a regular $\mathrm{Zn}$ decrease in the deeper horizons of the amended soil, in relation with the decrease in amphibole weathering intensity and, accordingly, a decrease in smectite content and sorption capacity with depth.

Conversely, the Zn concentration profiles obtained from the plagioclases weathering microsites (Figure 4(c)) show a Zn depletion of the clay minerals in the amended surface horizons and a Zn enrichment deeper in the amended soil. This particular behaviour appears to be controlled by the clay mineral weathering sequence of plagioclases. Kaolinite with low sorption capacity of 16 to $34 \mathrm{cmol} \cdot \mathrm{kg}^{-1}$ [35] [36] crystallizes at the top of the amended soil and does not retain $\mathrm{Zn}$. Thus, Zn can migrate downwards to more smectitic assemblages (K/S) and finally to montmorillonite where it is retained at $190 \mathrm{~cm}$ depth.

Although $\mathrm{Zn}$ concentrations in the fissural network of the amended soil are always higher than in the control soil, the general trend is similar for the $C$ and Bw horizons (Figure 4(d)) and typical of a downward migrating element. The behaviour of $\mathrm{Zn}$ in the surface horizons appears very different depending on whether one considers the control or the amended soil: $\mathrm{Zn}$ in the control soil behaves like a migrating element and follows the same trend as in $\mathrm{C}$ and Bw horizons; conversely, $\mathrm{Zn}$ in the amended soil shows a surface accumulation that can be directly related to the spreading of the sewage sludges.

Regardless of the sites studied, the present work points out the migration of $\mathrm{Zn}$ within the sludge-amended soil profile. The mineralogical multiscale approach demonstrates that such a behaviour is highly controlled by the clay minerals and their associated sorption capacities. Clays study is thus essential to understand the sorption 
reactions occurring at the solid/solution interface in soils. As demonstrated in this paper, the clayey components in the soils are complex assemblages of several clay minerals which formed in distinct weathering microsystems with their own physicochemical properties. Therefore, there is a need for accurate studies at the scale of these weathering microsystems to identify each clay mineral species in order to infer the sorption capacity of the weathering microsite, and to estimate the potential mobility of the heavy metals in the contaminated soils. This micrometric mineralogical approach could be relevant to describe the location and the behaviour of heavy metals in contaminated soils and improve the modeling of the heavy metals surface complexation in soils [37].

\section{References}

[1] Planquart, P., Bonin, G., Prone, A. and Massiani, C. (1999) Distribution, Movement and Plant Availability of Trace Metals in Soils Amended with Sewage Sludge Compost: Application to Low Metal Loadings. Science of the Total Environment, 241, 161-179. http://dx.doi.org/10.1016/S0048-9697(99)00338-1

[2] Baize, D. and Sterckeman, T. (2001) Of the Necessity of Knowledge of the Natural Pedo-Geochemical Background Content in the Evaluation of the Contamination of Soils by Trace Elements. Science of the Total Environment, 264, 127-139. http://dx.doi.org/10.1016/S0048-9697(00)00615-X

[3] Horckmans, L., Swennen, R., Deckers, J. and Maquil, R. (2005) Local Background Concentrations of Trace Elements in Soils: A Case Study in the Grand Duchy of Luxembourg. Catena, 59, 279-304. http://dx.doi.org/10.1016/j.catena.2004.09.004

[4] Sterckeman, T., Douay, F., Baize, D., Fourier, H., Proix, N. and Schvartz, C. (2006) Trace Elements in Soils Developed in Sedimentary Materials from Northern France. Geoderma, 136, 912-929. http://dx.doi.org/10.1016/j.geoderma.2006.06.010

[5] Huang, B., Kuo, S. and Bembenek, R. (2004) Availability of Cadmium in Some Phosphorous Fertilizer s to FieldGrown Lettuce. Water, Air, and Soil Pollution, 158, 37-51. http://dx.doi.org/10.1023/B:WATE.0000044832.04770.41

[6] Mbila, M.O., Thompson, M.L., Mbagwu, J.S.C. and Laird, D.A. (2001) Distribution and Movement of Sludge-Derived Trace Metals in Selected Nigerian Soils. Journal of Environmental Quality, 30, 1667-1674. http://dx.doi.org/10.2134/jeq2001.3051667x

[7] Hernandez, L., Probst, A., Probst, J.L. and Ulrich, E. (2003) Heavy Metal Distribution in Some French Forest Soil: Evidence for Atmospheric Contamination. Science of the Total Environment, 312, 195-219. http://dx.doi.org/10.1016/S0048-9697(03)00223-7

[8] Kraepiel, A.M.L., Keller, K. and Morel, F.M.M. (1999) A Model for Metal Adsorption on Montmorillonite. Journal of Colloid and Interface Science, 210, 43-54. http://dx.doi.org/10.1006/jcis.1998.5947

[9] Srivastava, P., Singh, B. and Angove, M. (2005) Competitive Adsorption Behavior of Heavy Metals on Kaolinite. Journal of Colloid and Interface Science, 290, 28-38. http://dx.doi.org/10.1016/j.jcis.2005.04.036

[10] Zhu, J., Cozzolino, V., Pigna, M., Huang, Q., Caporale, A.G. and Violante, A. (2011) Sorption of Cu, Pb and Cr on Na-Montmorillonite: Competition and Effect of Major Elements. Chemosphere, 84, 484-489. http://dx.doi.org/10.1016/j.chemosphere.2011.03.020

[11] Farrah, H., Hatton, D. and Pickering, W.F. (1980) The Affinity of Metal Ions for Clay Surfaces. Chemical Geology, 28, 55-68. http://dx.doi.org/10.1016/0009-2541(80)90035-2

[12] Wahba, M.M. and Zaghloul, A.M. (2007) Adsorption Characteristics of Some Heavy Metals by Some Soil Minerals. Journal of Applied Sciences Research, 3, 421-426.

[13] Wilson, M.J. (2004) Weathering of the Primary Rock-Forming Minerals: Processes, Products and Rates. Clay Minerals, 39, 233-266. http://dx.doi.org/10.1180/0009855043930133

[14] Caillaud, J., Proust, D. and Righi, D. (2006) Weathering Sequences of Rock-Forming Minerals in a Serpentinite: Influence of Microsystems on Clay Mineralogy. Clays and Clay Minerals, 54, 87-100. http://dx.doi.org/10.1346/CCMN.2006.0540111

[15] Proust, D., Caillaud, J. and Fontaine, C. (2006) Clay Minerals in Early Amphibole Weathering: Tri- to Dioctahedral Sequence as a Function of Crystallization Sites in the Amphibole. Clays and Clay Minerals, 54, 351-362. http://dx.doi.org/10.1346/CCMN.2006.0540306

[16] Keller, C., McGrath, S.P. and Dunham, S.J. (2002) Trace Metal Leaching through a Soil-Grassland System after Sewage Sludge Application. Journal of Environmental Quality, 31, 1550-1560.

[17] Martinez Cortizas, A., Garcia-Rodeja Gayoso, E., Novoa Munoz, J.C., Pontevedra Pombal, X., Burman, P. and Terribile, F. (2003) Distribution of Some Selected Major and Trace Elements in Four Italian Soils Developed from the Deposits of the Gauro and Vico Volcanoes. Geoderma, 117, 215-224. http://dx.doi.org/10.1016/S0016-7061(03)00124-1 
[18] Atteia, O., Thélin, P., Pfeifer, H.R., Dubois, J.P. and Hunziker, J.C. (1995) A Search for the Origin of Cadmium in the Soil of the Swiss Jura. Geoderma, 68, 149-172. http://dx.doi.org/10.1016/0016-7061(95)00037-O

[19] Hardy, M. and Cornu, S. (2006) Location of Natural Trace Elements in Silty Soils Using Particle-Size Fractionation. Geoderma, 133, 295-308. http://dx.doi.org/10.1016/j.geoderma.2005.07.015

[20] Camuti, K.S. and McGuire, P.T. (1999) Preparation of Polished Thin Sections from Poorly Consolidated Regolith and Sediment Materials. Sedimentary Geology, 128, 171-178. http://dx.doi.org/10.1016/S0037-0738(99)00073-1

[21] Fialin, M., Rémy, H., Richard, C. and Wagner, C. (1999) Trace Element Analysis with the Electron Microprobe: New Data and Perspectives. American Mineralogist, 84, 70-77.

[22] Baize, D. (1997) Teneurs totales en Eléments Traces métalliques dans les sols (France). INRA, Paris, 408 p.

[23] Scokart, P.O., Meeus-Verdinne, K. and De Borger, R. (1983) Mobility of Heavy Metals in Polluted Soils. Water, Air, and Soil Pollution, 20, 451-463. http://dx.doi.org/10.1007/BF00208519

[24] Arslan, M., Abdioglu, E. and Kadi, S. (2010) Mineralogy, Geochemistry, and Origin of Bentonite in Upper Cretaceous Pyroclastic Units of the Tirebolu Area, Giresun, Northeast Turkey. Clays and Clay Minerals, 58, 120-141. http://dx.doi.org/10.1346/CCMN.2010.0580112

[25] Karakaya, M.C., Karakaya, N. and Kupeli, S. (2011) Mineralogical and Geochemical Properties of the Na- and CaBentonites of Ordu (NE Turkey). Clays and Clay Minerals, 59, 75-94. http://dx.doi.org/10.1346/CCMN.2011.0590109

[26] Jeong, G.Y. (2000) The Dependence of Localized Crystallization of Halloysite and Kaolinite on Primary Minerals in the Weathering Profile of Granite. Clays and Clay Minerals, 48, 196-203. http://dx.doi.org/10.1346/CCMN.2000.0480205

[27] Papoulis, D., Tsolis-Katagas, P. and Katagas, C. (2004) Progressive Stages in the Formation of Kaolin Minerals of Different Morphologies in the Weathering of Plagioclase. Clays and Clay Minerals, 52, 275-286. http://dx.doi.org/10.1346/CCMN.2004.0520303

[28] Coles, C.A. and Yong, R.N. (2002) Aspects of Kaolinite Characterization and Retention of Pb and Cd. Applied Clay Science, 22, 39-45. http://dx.doi.org/10.1016/S0169-1317(02)00110-2

[29] Eloussaief, M. and Benzina, M. (2010) Efficiency of Natural and Acid-Activated Clays in the Removal of Pb(II) from Aqueous Solutions. Journal of Hazardous Materials, 178, 753-757. http://dx.doi.org/10.1016/j.jhazmat.2010.02.004

[30] Farrah, H. and Pickering, W.F. (1977) Influence of Clay-Solute Interactions on Aqueous Heavy Metal Ion Levels. Water, Air, and Soil Pollution, 8, 189-197. http://dx.doi.org/10.1007/BF00294042

[31] Veli, S. and Alyüz, B. (2007) Adsorption of Copper and Zinc from Aqueous Solutions by Using Natural Clay. Journal of Hazardous Materials, 149, 226-233. http://dx.doi.org/10.1016/j.jhazmat.2007.04.109

[32] Kirkham, M.B. (2006) Cadmium in Plants on Polluted Soils: Effects of Soil Factors, Hyperaccumulation, and Amendments. Geoderma, 137, 19-32. http://dx.doi.org/10.1016/j.geoderma.2006.08.024

[33] Ayari, F., Srasra, E. and Trabelsi-Ayadi, M. (2005) Characterization of Bentonitic Clays and Their Use as Adsorbent. Desalination, 185, 391-397. http://dx.doi.org/10.1016/j.desal.2005.04.046

[34] Srodon, J. and McCarty, D.K. (2008) Surface Area and Layer Charge of Smectite from CEC and EGME/H2O-Retention Measurements. Clays and Clay Minerals, 56, 155-174. http://dx.doi.org/10.1346/CCMN.2008.0560203

[35] Ferris, A.P. and Jepson, W.B. (1975) The Exchange Capacities of Kaolinite and the Preparation of Homoionic Clays. Journal of Colloid and Interface Science, 51, 245-259. http://dx.doi.org/10.1016/0021-9797(75)90110-1

[36] Ma, C. and Eggleton, R.A. (1999) Cation Exchange Capacity of Kaolinite. Clays and Clay Minerals, 47, 174-180. http://dx.doi.org/10.1346/CCMN.1999.0470207

[37] Hizal, J. and Apak, R. (2006) Modeling of Copper (II) and Lead (II) Adsorption on Kaolinite-Based Clay Minerals Individually and in the Presence of Humic Acid. Journal of Colloid and Interface Science, 295, 1-13. http://dx.doi.org/10.1016/j.jcis.2005.08.005 